\title{
Risk management in maritime transport of goods through insurance
}

\author{
Milen Mitkov ${ }^{1 *}$, Sergey Radukanov ${ }^{2}$, and Mariana Petrova ${ }^{3}$ \\ ${ }^{1}$ Air Force Academy „Georgy Benkovski“, Dolna Mitropolia, Bulgaria \\ ${ }^{2,3}$ St. Cyril and St. Methodius University of Veliko Tarnovo, Veliko Tarnovo, Bulgaria
}

\begin{abstract}
The present study, the issues related to the development and features of Cargo insurance are considered as a way to manage the risk in the maritime transport of goods and cargo. The state, tendencies and prospects for development of this type of insurance are outlined, as well as the gross domestic product of the country. The study period is 2010-2019, ie the years after Bulgaria's accession to the European Union. The results of the analysis confirm the strong link between maritime transport and insurance of transported goods and cargo, which leads to strong development in the insurance market as a whole. It was established that the rate of development of the gross domestic product of the country lags behind the rate of development of the transported goods and cargo by sea. On the other hand, the pace of development of freight insurance outpaces the pace of development of goods transported by sea and the rate of development of the country's gross domestic product.
\end{abstract}

\section{Introduction}

A lot of businesses are looking for innovative ways to improve efficiency and maintain competitive advantage in order to survive [1-3]. The economic purpose of maritime transport is to be transported from one place to another created by other mirror products, as the processes of relocation and consumption of its useful effect are photographed and compared over time. Unlike rail and road transport, maritime transport cannot be equipped anywhere in the country. It can be used only in areas that have suitable natural conditions the presence of seas, large navigable rivers, conditions for digging artificial canals and others.

Many Bulgarian and foreign authors have worked and expressed their opinions competently on the problems of the economy as a whole and insurance. In this field we can distinguish part of the research of Pukala [4, 5], Mitkov [6], Bacho, Hkibko, Vnukova, Pola [7], Sushchenko [8], whose multi-layered analysis has enriched and expanded knowledge in this area. In this way solutions to important problems of economic and managerial practice are given from the standpoint of modern scientific achievements.

The problem of organizing efficient economics and innovation activity invoked great scientific interests of Ukrainian and Latvian researchers, such as Ponomarenko, Malyaretz,

*Corresponding author: m.petrova@ts.uni-vt.bg 
Dorokhov, Matyushenko, Hlibko, Pasmor, Loktionova, Jarmusevica, Ilisko, Badjanova, Jukss, Komarova, Selivanova-Fyodorova, Ruza, Kaźmierczyk, Arbidane [9-12].

Compared to other modes of transport, water has the ability to perform mass international transport of goods, and during the transport there are many risks. Therefore, the study of the risks associated with the carriage of goods by sea is of particular importance. One way to manage these risks is through insurance of transported goods and cargo. Through it, the risk is transferred from the sea carrier to the insurance company. The role of insurance for the maritime carrier of goods is reduced to indemnification of those insured who suffer losses in the realization of risks included in the liability of the insurer. Insurance protection is therefore a support tool for entities that bear the risk associated with their activity [7].

The insurance provides insurance coverage covering partial damages or complete loss of cargo and related property interests during transport for loss or damage, which are a direct consequence of the occurrence of covered insurance risk. The object of the insurance are the goods transported by water, land and air. The goods are insured by pieces, parcels, connections or crates as indicated in the transport documents, and in the case of goods transported in bulk or in bulk - by weight units. The purpose of insurance is to transfer responsibility for the risk of loss of or damage to cargo from the buyer or seller of goods to the insurer.

The specialized nature of the Cargo insurance is an essential prerequisite for any increase or decrease in the economic activity in the country to reflect on the increase or decrease of the share of the insurance in the total volume of the concluded insurance contracts.

According to the definitions of "insured interest" adopted in world theory and practice, the property interest that the insurer has in relation to the insured object. Insurance is the optimal risk transfer instrument for an enterprise [4]. It is present when the insured has a direct material interest in the fate of the subject of the insurance. Depending on the conditions under which the specific delivery is agreed in the given transaction, the seller or the buyer, as well as the forwarders, banks, owners of transit warehouses, etc., may be interested in the insurance. Carriers are also interested in its existence, because although the insurance of the goods they transport does not release them from liability, it greatly reduces their risks from circumstances beyond their control. It should be emphasized that risk management is a very important tool in the operations of enterprises for monitoring and reducing the risk of operations [5].

The moment of the transfer of ownership of the goods from the seller to the buyer determines who is the bearer of the insured interest at the time, and hence who will be a party to the insurance contract. Given the change in ownership, the interest holder also changes. In the case of transport insurance, the bearer of the insured interest is always the person who bears the risks of loss of or damage to the transported cargo. Therefore, in commercial transactions, the moment for the occurrence or transfer of the insured interest between the participants in the transaction is directly related to the moment for the transfer of the risk for the goods from the seller to the buyer. On the other hand, the moment for passing the risk depends on the conditions of the specific delivery and the franking of the agreed price.

This study focuses on the development of cargo insurance in the context of risk management of the maritime carrier of goods and cargo, and the subject - on the economic, legal and technical possibilities, features and problems faced by maritime carriers in concluding of Cargo insurance.

The goal is to analyze and assess the state and trends in the development of cargo insurance in Bulgaria and to outline the trends in development.

In order to achieve a formulated goal, it is necessary to consider the following tasks: 
- summarization and systematization of theoretical formulations for cargo insurance;

- analysis of the dynamics of the gross domestic product in Bulgaria for the period (2010-2019)

- analysis of the condition of the transported goods by sea for the period (2010-2019);

- analysis of the state of the insurance market in Bulgaria for the period (2010-2019);

- analysis of the condition of the cargo insurance for the period (2010-2019).

\section{Materials and Methods}

To achieve the main goal of the study, modern approaches and methods are used, such as: method of analysis and synthesis; inductive and deductive method, empirical approach, comparative method and logical description

All results refer to the respective sources of information of the National Statistical Institute of the Republic of Bulgaria, the Financial Supervision Commission, Eurostat or are based on the authors' own calculations. The main statistical data for the analyzes in the separate parts of the survey are taken from the official websites of: National Statistical Institute, Financial Supervision Commission and Eurostat. They cover the period until 31.12.2019 and do not take into account the changes that occurred after it. The data are presented in tabular form using MS Office Excel 2010.

All results refer to the relevant sources of information of the National Statistical Institute of the Republic of Bulgaria, the Financial Supervision Commission, Eurostat or are based on the authors' own calculations.

\section{Results}

\subsection{Research and analysis in the development of the gross domestic product in Bulgaria for the period 2010-2019}

One of the indicators for measuring economic activity is the gross domestic product. Along with labor productivity, it is one of the most important indicators determining the development of an economy. The most significant can be defined as the final result of the production activity of economic entities in the country. In today's rapidly changing socioeconomic environment, the problem of sustainable development is becoming increasingly relevant as a concept for achieving environmentally friendly economic development of society. On the basis of the data obtained for the gross domestic product, the income of the population as well as its purchasing power can be estimated.

There are three main approaches to measuring gross domestic product: production, revenue and expenditure.

Gross domestic product, calculated by the production method, characterizes the final result of economic activity and is measured by the value added created in the production of goods and services by units resident in the economic territory of the country. Value added is the difference between the value of the final goods and the intermediate goods used to produce them. To the sum of the value added of all goods by producers in the national economy are added the net taxes (reduced by subsidies) and the value of the gross domestic product is obtained.

Under the production method, GDP at market prices is calculated as the sum of gross value added at basic prices total for the economy and adjustments, which include net taxes on products, non-deductible value added tax and import duties.

In the income approach, gross domestic product is presented as the sum of income received from resource providers, ie. by the owners of factors of production 
Through the cost approach, gross domestic product is calculated on the basis of the monetary costs incurred by all producers of finished products.

The data in Table 1. and Fig. 1 show that after 2010 the rate of development of the gross domestic product in Bulgaria is growing significantly. The most significant reason for this is the high growth of foreign direct investment during this period. In the period after 2010, the annual growth of gross domestic product per capita was on average about $1.8 \%$. The slow but real growth of the economy after 2010 is largely due to the stable banking system, the currency board, as well as EU funds. The absorption of EU funds has a significant impact on the positive growth of the economy. By 2018, euro funds contribute to over $32 \%$ of total investments in the economy. Therefore, the funds from the Euro funds, which flow into the Bulgarian economy in the form of government expenditures, compensate to some extent for the outflow of foreign direct investment.

Table 1. Gross domestic product, growth rate for the period 2010-2019 (in \%)

\begin{tabular}{|l|c|c|c|}
\hline Years & $\begin{array}{c}\text { GDP (billion } \\
\text { BGN) }\end{array}$ & $\begin{array}{c}\text { Compared to } \\
\mathbf{2 0 1 0}\end{array}$ & $\begin{array}{c}\text { Compared previous } \\
\text { year }\end{array}$ \\
\hline $\mathbf{2 0 1 0}$ & 73,214 & $\mathrm{x}$ & $\mathrm{x}$ \\
\hline $\mathbf{2 0 1 1}$ & 78,221 & 6,8 & 1,6 \\
\hline $\mathbf{2 0 1 2}$ & 80,941 & 9,5 & 1,8 \\
\hline $\mathbf{2 0 1 3}$ & 81,357 & 10,9 & 0,5 \\
\hline $\mathbf{2 0 1 4}$ & 82,910 & 12,3 & 2,0 \\
\hline $\mathbf{2 0 1 5}$ & 86,792 & 17,8 & 3,3 \\
\hline $\mathbf{2 0 1 6}$ & 92,635 & 26,0 & 3.8 \\
\hline $\mathbf{2 0 1 7}$ & 102,300 & 39,7 & 3,6 \\
\hline $\mathbf{2 0 1 8}$ & 109,700 & 49,3 & 3,1 \\
\hline $\mathbf{2 0 1 9}$ & 118,670 & 61,6 & 3,4 \\
\hline
\end{tabular}

Source: own calculations, based on National Statistical Institute of the Republic of Bulgaria

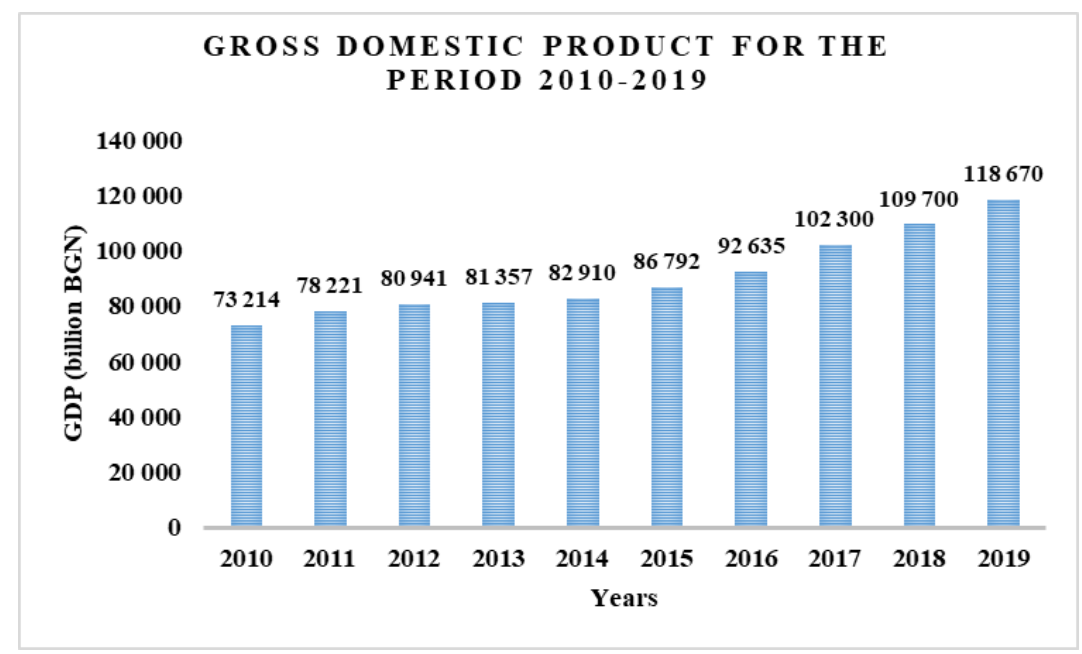

Fig.1. Gross domestic product for the period 2010-2019 (in BGN)

During the period 2010-2019 in Table 1, there is a continuous economic growth both compared to the base year and to each subsequent year. In 2019, compared to 2010, the gross domestic product increased by a little over BGN 45 million or by $62 \%$.

There are several main objectives of economic policy, the priority of which depends on the specific state in which the economy is. These goals can be summarized in the following: 
price stability (low inflation); high level of employment (or natural rate of unemployment); maintaining positive foreign trade balances and sustainable economic growth

\subsection{Analysis of the condition of the transported goods by sea for the period for the period 2010-2019}

The transported goods from the river and sea transport at the end of 2019 are 30997 thousand tons, which is an increase of $11.2 \%$ compared to the previous 2018 . From the data in Table 2 it is established that the export of goods and cargo has a significant share compared to the import of goods and cargo

Table 2.Goods and goods transported by sea in Bulgaria for period 2010-2019.

\begin{tabular}{|c|c|c|c|c|}
\hline Years & $\begin{array}{c}\text { Import unloaded } \\
\text { /thousand tons/ }\end{array}$ & $\begin{array}{c}\text { Export loaded } \\
\text { / thousand tons/ }\end{array}$ & $\begin{array}{c}\text { Total } \\
\text { / thousand tons/ }\end{array}$ & $\begin{array}{c}\text { Growth rate } \\
\%\end{array}$ \\
\hline $\mathbf{2 0 1 0}$ & 11847 & 11089 & 22946 & $\mathrm{X}$ \\
\hline $\mathbf{2 0 1 1}$ & 13036 & 12149 & 25185 & 9,8 \\
\hline $\mathbf{2 0 1 2}$ & 12722 & 13290 & 26012 & 3,3 \\
\hline $\mathbf{2 0 1 3}$ & 12503 & 16338 & 28841 & 10,9 \\
\hline $\mathbf{2 0 1 4}$ & 12299 & 14936 & 27235 & $-5,6$ \\
\hline $\mathbf{2 0 1 5}$ & 12622 & 14544 & 27166 & $-0,3$ \\
\hline $\mathbf{2 0 1 6}$ & 13115 & 15570 & 28685 & 5,6 \\
\hline $\mathbf{2 0 1 7}$ & 14184 & 16769 & 30953 & 7,9 \\
\hline $\mathbf{2 0 1 8}$ & 13046 & 14822 & 27868 & $-10,0$ \\
\hline $\mathbf{2 0 1 9}$ & 14770 & 16227 & 30997 & 11,2 \\
\hline
\end{tabular}

Source: own calculations, based on Eurostat

The data in Table 2 show that the rate of development of the transport of goods and cargo is ahead of the rate of development of the country's gross domestic product. The average rate of development of transported goods and cargo for the period from 2010 to 2019 is $7.6 \%$.

The main characteristics of ports and inland infrastructure facilities, as well as the type of goods transported, are some of the elements that significantly influence the choice of maritime transport. The European Union is heavily dependent on seaports for trade with the rest of the world and within its internal market, accounting for $74 \%$ of trade (imports and exports) with the rest of the world.

Ports ensure the territorial connectivity of the countries of the European Union by servicing regional and local maritime traffic to connect with peripheral and island areas. They are the hubs from which multimodal logistics flows can be organized across the transEuropean network, using short sea shipping links, railways and inland waterways to minimize the strain on road infrastructure and energy consumption.

\subsection{Analysis of the state of the insurance market in Bulgaria for the period 2010-2019}

A country's economy is a dynamic system that develops depending on the socio-political relations that dominate it. Creating everything necessary for the existence of society, it is one of the foundations for its development

In the process of economic development, the insurance activity also occupies its important place. The well-developed insurance sector is an integral part of any modern economic system, often it is part of stable economic growth, part of the high employment rate of the working population. In the highly integrated economic space of the European Union, the contribution of the insurance sector to the economies of the Member States is crucial. 
The provided insurance protection against the consequences of adverse events enables the companies and the citizens to receive monetary compensation and to cope with the occurred difficulties. In this sense, insurance helps to achieve stability in the economies of individual countries. The main measure of the condition and development of the insurance market is the gross premium income. The economic essence of premium income is manifested in the fact that it forms part of national income. It is generated by the insured in order to guarantee their interests from the harmful effects of adverse events

Table 3. Premium income of insurance companies in Bulgaria for period 2010-2019.

\begin{tabular}{|c|c|c|c|c|c|c|}
\hline \multirow{2}{*}{ Years } & $\begin{array}{c}\text { Non - live } \\
\text { insurance }\end{array}$ & Live insurance & $\begin{array}{c}\text { Total } \\
\text { premium } \\
\text { income }\end{array}$ & $\begin{array}{c}\text { Growth } \\
\text { rate }\end{array}$ & $\begin{array}{c}\text { Share of Non- } \\
\text { life insurance }\end{array}$ & $\begin{array}{c}\text { Share of } \\
\text { Life } \\
\text { insurance }\end{array}$ \\
\cline { 2 - 7 } & $\begin{array}{c}\text { Million } \\
\text { BGN }\end{array}$ & $\begin{array}{c}\text { Million } \\
\text { BGN }\end{array}$ & $\begin{array}{c}\text { Million } \\
\text { BGN }\end{array}$ & $\mathbf{\%}$ & $\%$ & $\%$ \\
\hline $\mathbf{2 0 1 0}$ & 1374,7 & 248,6 & 1623,4 & X & 84,7 & X \\
\hline $\mathbf{2 0 1 1}$ & 1362,0 & 251,7 & 1613,7 & $-0,8$ & 84,4 & 15,6 \\
\hline $\mathbf{2 0 1 2}$ & 1336,0 & 268,0 & 1604,1 & $-0,6$ & 83,3 & 16,7 \\
\hline $\mathbf{2 0 1 3}$ & 1423,4 & 305,9 & 1729,4 & 7,7 & 82,3 & 17,7 \\
\hline $\mathbf{2 0 1 4}$ & 1434,3 & 340,6 & 1774,9 & 2,6 & 80,8 & 19,2 \\
\hline $\mathbf{2 0 1 5}$ & 1573,0 & 391,2 & 1964,3 & 9,9 & 80,1 & 19,9 \\
\hline $\mathbf{2 0 1 6}$ & 1622,2 & 428,3 & 2050,6 & 4,21 & 79,1 & 21,9 \\
\hline $\mathbf{2 0 1 7}$ & 1748,7 & 428,6 & 2177,4 & 6,2 & 80,3 & 19,7 \\
\hline $\mathbf{2 0 1 8}$ & 2047,1 & 430,1 & 2477,2 & 11,4 & 82,6 & 17,4 \\
\hline $\mathbf{2 0 1 9}$ & 2383,3 & 477,3 & 2860,6 & 11,6 & 83,3 & 17,7 \\
\hline
\end{tabular}

Source: own calculations, based on Financial Supervision Commission

The data in Table 3 show that in 2019 the gross premium income of all insurance companies in the country reached nearly 2.9 billion. There is also a steady trend towards an increase in premium income for the entire period of the survey. The rate of development of premium income for the period 2010-2019 ranges from $-3.50 \%$ to $9.90 \%$. In the years up to 2008 the rate of development ranges from $16.62 \%$ to $28.16 \%$. The crisis in the period after 2008 also affected the insurance market.

The data in the table show that in the period from 2010 to 2012 there is a negative rate of development, which ranges from $-0.60 \%$ to $-3.50 \%$. A good trend can be noted the positive pace of development of premium income after 2013, as at the end of 2018 and 2019. an increase of over $10 \%$ is observed. For the entire period of the study from 2010 . until 2019 the rate of development of the premium income is $76.2 \%$. The growth of premium income is mainly due to the liability under the Civil Liability Insurance, Credit and Guarantee Insurance

During the period 2010-2019. the tendency of permanent increase of the importance of life insurance for the development of the insurance market and the economy is confirmed, after which in recent years this importance decreases. The outpacing pace of development of life insurance compared to non-life insurance led to an increase in the share of life insurance in gross premium income. If the relative share of life insurance in relation to premium income was before Bulgaria's accession to the European Union within $10 \%$ or a ratio of 9:1 in favor of non-life insurance, then in 2017 the share is already about $20 \%$ or the ratio is 8:2. However, this is still far from the usual European practice, where life insurance is predominant.

\subsection{Analysis of the state of cargo insurance for the period 2010-2019}

The following presentation presents the development of Cargo insurance over a relatively long period, covering the period after the global crisis of 2007. 
Table 4. Premium income on cargo insurance in Bulgaria for period 2010-2019.

\begin{tabular}{|c|c|c|c|c|}
\hline Years & $\begin{array}{c}\text { Non - live insurance } \\
\text { Million BGN }\end{array}$ & $\begin{array}{c}\text { Growth rate } \\
\mathbf{\%}\end{array}$ & $\begin{array}{c}\text { Cargo insurance } \\
\text { Million BGN }\end{array}$ & $\begin{array}{c}\text { Growth rate } \\
\text { \% }\end{array}$ \\
\hline $\mathbf{2 0 1 0}$ & 1374,7 & $\mathrm{x}$ & 13,7 & $\mathrm{x}$ \\
\hline $\mathbf{2 0 1 1}$ & 1362,0 & $-0,9$ & 15,2 & 10,9 \\
\hline $\mathbf{2 0 1 2}$ & 1336,0 & $-1,9$ & 14,6 & $-3,6$ \\
\hline $\mathbf{2 0 1 3}$ & 1423,4 & 6,5 & 15,8 & 8,4 \\
\hline $\mathbf{2 0 1 4}$ & 1434,3 & 0,1 & 15,6 & $-1,2$ \\
\hline $\mathbf{2 0 1 5}$ & 1573,0 & 9,7 & 17,2 & 9,7 \\
\hline $\mathbf{2 0 1 6}$ & 1622,2 & 3,1 & 21,2 & 23,3 \\
\hline $\mathbf{2 0 1 7}$ & 1748,7 & 7,8 & 18,2 & $-14,1$ \\
\hline $\mathbf{2 0 1 8}$ & 2047,1 & 11,7 & 17,9 & $-1,7$ \\
\hline $\mathbf{2 0 1 9}$ & 2383,3 & 11,7 & 18,9 & 5,6 \\
\hline
\end{tabular}

Source: own calculations, based on Financial Supervision Commission

The data in Table 4 show that in 2019 the gross premium income from cargo insurance exceeds BGN 18 million, reaching BGN 18.9 million. The following development trend is established: in the years from the initial research period the income increases, then gradually decreases, alternating years of positive and negative rate of development in 6 consecutive years. The pace of development of premium income for the period 20010-2019 ranges from $-14.1 \%$ to $23.6 \%$.

The data in the table show that at the end of the study period in 2019 the revenue increased by over $5 \%$ compared to the previous 2018 . The significant increase in trade and the favorable monetary policy pursued by the leading industrialized countries maintain high levels of trade. Thus, for the period 2010-2019 we observe a certain decline, which is due more to the choice of the owners of the transported goods to rely on another insurance contract - "Liability of the carrier", despite the limited coverage it provides. Due to its specific nature, Cargo insurance affects the interests of a relatively small circle of economic business units and entities. This inevitably leads to a decline, and sometimes to a lack of a solid and sustainable marketing policy by the licensed companies in order to promote it.

It should be noted that the decrease in the amount of collected premiums is due not only to the low levels of trade and the smaller number of concluded contracts, but also to the decrease in the prices of transported raw materials, which reflects on the insurance values, on the insurance amounts under contracts, and hence on the required premiums.

Table 5. Market share of cargo insurance in Bulgaria for period 2010-2019.

\begin{tabular}{|c|c|c|}
\hline Years & $\begin{array}{c}\text { Cargo insurance } \\
\text { (Million BGN) }\end{array}$ & $\begin{array}{c}\text { Market share } \\
\mathbf{( \% )}\end{array}$ \\
\hline $\mathbf{2 0 1 0}$ & 13,7 & 0,99 \\
\hline $\mathbf{2 0 1 1}$ & 15,2 & 1,11 \\
\hline $\mathbf{2 0 1 2}$ & 14,6 & 1,09 \\
\hline $\mathbf{2 0 1 3}$ & 15,8 & 1,11 \\
\hline $\mathbf{2 0 1 4}$ & 15,6 & 1,09 \\
\hline $\mathbf{2 0 1 5}$ & 17,2 & 1,09 \\
\hline $\mathbf{2 0 1 6}$ & 21,2 & 1,38 \\
\hline $\mathbf{2 0 1 7}$ & 18,2 & 1,21 \\
\hline $\mathbf{2 0 1 8}$ & 17,9 & 0,87 \\
\hline $\mathbf{2 0 1 9}$ & 18,9 & 0,79 \\
\hline
\end{tabular}

Source: own calculations, based on Financial Supervision Commission www.fsc.bg 
The data in Table 5 show that for the period 2010-2019 there is a steady trend towards maintaining the market share of cargo insurance within $0.8-1.10 \%$. It is no secret that until recently, cargo insurance, especially for domestic deliveries, did not receive much attention. For several years, the trend has been to pay more attention to these insurances. When we have land transport, traders often save on cargo insurance, relying on the liability of the carrier, which sometimes leads to losses.

From the above it can be concluded that the development of sales of insurance "Freight during transport" is not directly dependent only on trends in the Bulgarian insurance market. The increase in sales and premium income under this type of insurance also largely depends on international trade and the tendency of exporters and importers of goods to transfer the risk to insurers.

\section{Discussion}

A country's economy is a dynamic system that develops depending on the socio-political relations that dominate it. In recent years, Bulgaria is facing a significant demographic crisis, which is characterized by declining and aging population. The country's gross domestic product is constantly growing, which is a prerequisite for sustainable economic growth. On the other hand, a stable and sustainable economy is a prerequisite for increasing foreign direct investment, which will lead to even greater development and turn the country as a regional factor in Central and Eastern Europe. In recent years, sustainable development has been established in the transport of goods and cargo by sea to and from the country. The results show that the rate of development of transported goods and cargo by sea significantly the rate of development of the country's gross domestic product.

The insurance market is an integral part of any modern economic system, and often it is part of stable economic growth. Based on the research, it was established that Cargo insurance has a huge potential for development in the coming years. Growing economic activity in the country and the related transport of goods and cargo by sea is expected to significantly increase the share of insurance of "Cargo during transport" or the so-called "Cargo" insurance, in the total volume of insurance contracts. The reason for this is that this type of insurance is directly related to the economic situation in the country.

\section{Conclusions}

Based on the study, it is established that Cargo insurance has great potential for development in the coming years. The growing economic activity in the country and the implementation of this transportation of goods and cargo by sea is expected to increase the share of insurance of "Cargo during transportation" or the so-called "Cargo" insurance, in the next volume of excluded insurance contracts. The reason for this is that this type of insurance is directly supported by the economic situation in the country. The policy cannot be sold in the country where there is no developed business, because it is used by sea carriers. The gradual stabilization of economic activity in the external environment has had a positive effect on exports of goods and services by sea.

A country's economy is a dynamic system that develops depending on the sociopolitical relations that dominate it. In recent years, Bulgaria is facing a significant demographic crisis, which is characterized by declining and aging population. There are several main objectives of economic policy, the priority of which depends on the specific state in which the economy is. These goals can be summarized in the following: price stability (low inflation); high level of employment (or natural rate of unemployment); maintaining positive foreign trade balances and sustainable economic growth. 


\section{References}

1. Yankovyi, O., Goncharov, Y., Koval, V., \& Lositska, T. (2019). Optimization of the capital-labor ratio on the basis of production functions in the economic model of production. Naukovyi Visnyk Natsionalnoho Hirnychoho Universytetu, 4, 134-140.

2. Mushkudiani, Z., Gechbaia, B., Gigauri, I., \& Gulua, E. (2020). Global, economic and technological trends in human resource management development. Access Journal, 1(1), 53-60. https://doi.org/10.46656/access.2020.1.1(4) (2020).

3. Baklanova, O., Petrova, M., \& Koval, V. (2020). Institutional transmission in economic development, Ikonomicheski Izsledvania (Economic Studies), 29(1), 68-91.

4. Pukala, R. (2016). Use of neural networks in risk assessment and optimization of insurance cover in innovative enterprises. E\&M, 8 (3). doi.org/10.1515/emj-2016-0023

5. Pukala, R., \& Petrova, M. (2019). Application of the AHP Method to Select an Optimal Source of Financing Innovation in the Mining Sector, IVth International Innovative Mining Symposium, E3S 105, 04034, https://doi.org/10.1051/e3sconf/201910504034.

6. Mitkov, M. (2018). Status and trends in the development of macroeconomic indicators "Insurance penetration" and "Insurance density" in Bulgaria (1997-2016). SEA, 10(1), 34-44.

7. Bacho, R., Pukala, R., Hlibko, S., Vnukova, N., \& Pola, P. (2019). Information Management: The Key Driver of the Economic System's Development. Marketing and Management of Innovations, 3. p. 297-307. http://doi.org/10.21272/mmi.2019.3-23

8. Sushchenko, O.A. (2015). Global shifts as aspects of globalization impact on foreign economic activity management. Contribution to Intern.Economy, 1,41-48.

9. Matyushenko, I., Hlibko, S., Petrova, M. M., Pasmor, M. S., \& Loktionova, M. (2020). Assessment of the development of foreign trade in high-tech production of Ukraine under the association with the EU. Business, Management and Education, 18(1), 157182.

10. Jarmuševiča, V., Iliško, D., Badjanova, J., Jukšs, V., \& Petrova, M. (2019). SMART governance of implementing the strategy of corporate societal responsibility for a sustainable regional development. Proceedings of the Int.Multidisciplinary Scientific GeoConference Surveying Geology and Mining Ecology Management, SGEM 19(5.3), pp. 645-652,

11. Ponomarenko, V., Malyaretz, L., Dorokhov, O. (2011). Genesis and methodological foundations of multidimensional data analysis in the social and economic system. Montenegrin Journal of Economics, 7 (2), 111-120.

12. Komarova, V., Selivanova-Fyodorova, N., Ruza, O., Kaźmierczyk, J., Arbidane, I. (2021. Modern trends in the economic differences between countries and within them: comparison of the world and the European Union, Entrepreneurship and Sustainability Issues, 8(3), 110-121. https://doi.org/10.9770/jesi.2020.8.3(6).) 